\title{
Effect of Home Environment upon Inferiority among School Going Students
}

\author{
Dr. Latika Varma ${ }^{1}$ *
}

\section{ABSTRACT}

A study conducted by Ministry of Home Affairs New Delhi. "Crime in India”, 1958 to 1964, it was found that most of the criminals came from broken homes where no code of discipline existed lack of interpersonal harmony and consistency leads to a viscous home atmosphere. The different hypothesis which was made for this study has been confirmed on the basis of the obtained data and statistical treatment. The proposal passed by UNO in chapter27, that every child in the world has the right to live and it is the parents responsibility to provide a congenial and harmonious home environment for the child, so that he can get various opportunities and motivation to develop skills, confidence and over all perfect personality.

\section{Keywords: Home Environment, Inferiority, School Students}

As we all know that $29^{\text {th }}$ Nov. 1989 was the day when UNO passed certain proposals for human rights. But they have given more emphasis on child welfare and child rights. In paragraph 27, it is clearly written that all children should be looked after properly by their parents for the proper mental, physical, academic, moral and social development. The child should get proper life-style to develop these qualities. He should get proper conditions \& environment at home, so that he develops his abilities and potentialities. At home, children should get financial aid and, the basic necessities of life.

Hence, the purpose of the present study is related to this aspect of child right in which effect of home environment upon inferiority is studied.

The social scientists have become more environmentally conscious. Their purpose is to study the relation between human behavior and physical environment. They want to know how a man perceives, acts and adapts to his physical, geographical and social environment. How he is

\footnotetext{
${ }^{1}$ Associate Professor, P.G Department Of Psychology, M.M. Mahila College, Ara, India *Responding Author

(C) 2016 I L Verma; licensee IJIP. This is an Open Access Research distributed under the terms of the Creative Commons Attribution License (http://creativecommons.org/licenses/by/2.0), which permits unrestricted use, distribution, and reproduction in any Medium, provided the original work is properly cited.
} 


\section{Effect of Home Environment upon Inferiority among School Going Students}

affected by the noise, temperature, slum dwellings which surround his home, the attitude of parents the group affiliation and the cultural norms.

Human beings are usually capable of passing from one environment to another, as well as of changing the conditions of a given environment to suit their own purpose. The environment is not simply the outside world though as something that surrounds us. Environment is present from the very formation of life. Environment is not one, but infinitely various. Every difference in our environment means difference in our habits, our ways of living.

There are two types of environment .The outer and the inner environment. The outer environment consists of the physical modification houses and cities etc. The inner environment is society endures.

The present study is designed to examine and explore the impact of social stratification of Home environment on the emotional aspect of personality. i.e., feeling of inferiority with' the following conceptualization:

(A) The Home Environment: - The environment exists in its complex totality, it is not the world about us but rather the world, with all its aspects, as it comes into relation to our lives. The more complex the life, the more complex will be the environment, and the more complex the adjustment to the total environment.

As we know family is the most important primary group in society. The home is the place providing an enduring accommodation to the family, within geographical, physical and social boundary. It may include collateral or subsidiary relationships, but it is constituted by the living together of mates.

The family has certain distinctive features such as university, limited size, nuclear position, permanent value.

The home environment relates to the operational roles of the family which is reflected through certain functions.

(1) Environmental Attachment:- Members of the family are attached with each other on impulses of basic nature. Right from maternal devotion and parental care the husband wife relationship is based on most intimate bond. The members of the family have cooperative and affectionate interdependent relationship.

(2) Responsibility Shared:- The members of the family have so much sense of responsibility that they toil for their families all their lives. They undertake heaviest responsibilities.

(3) Social Regulation:- The members are guarded by certain regulations imposed from the society the effect of home environment is reflected in socialization of the child. When the child

(C) The International Journal of Indian Psychology, ISSN 2348-5396 (e)| ISSN: 2349-3429 (p) | 116 


\section{Effect of Home Environment upon Inferiority among School Going Students}

is socialized in a happy, affectionate family, he usually develops a secure, well adjusted personality. When the family life is unsatisfactory, the children often develop personality difficulties and behavior deviants.

A study conducted by Ministry of Home Affairs New Delhi. "Crime in India”, 1958 to 1964, it was found that most of the criminals came from broken homes where no code of discipline existed lack of interpersonal harmony and consistency leads to a viscous home atmosphere. No two children will omit the same behavior. They may be of same age group with underlying identical psychological process that are common, yet they will exhibit variation in their behavioral aspects. The variation is due to their changed environment.

Family is the functional component of home and the first social institution of the child is his home. The home environment has its manifestations in the child's behaviour. Proper adaptability and adjustment is the outcome of a proper home environment. It is the home environment which provides typical system of life of the child. Family is the important component of home environment and the parents exercise a most dominant role in the home.

(B) The feeling of Inferiority: Feeling of deprivation, lowness is interiority. It is a conditional anything in the individual that is below the average that provides unfavorable comment or gives him a feeling or impotency, social and interpersonal deprivations is inferiority.

Development of such feeling, i.e. inferiority is usually accompanied by certain reactive factors. These reactions are of various kinds and from the indicative signs of existence of inferiority feelings. Feelings of shame, guilty, rejections, insulation, tension etc perception of word and life as dangerous, human beings as bad, leading to actions like putting up grievance, looking pathetic, begging, pleading, weeping, accepting; favours unhesitatingly do, serve as the sign of presence of feeling of inferiority (Maslow 1945).

Few factors play a major role in the development of feeling of inferiority. Physical Deprivation can act as predisposing or precipitating cause of inferiority feeling.

Malnourished children suffer from lowered mental \& physical capacity which further leads to serious deficits as feeling of inferiority. Brain pathology is also an important factor of development of feeling of inferiority. Organic brain disorders leads to mental incapacity hence development of feeling of inferiority is seen.

As these biological cause is responsible for development of inferiority, and also psychosocial factors are equally responsible for that. Psychological and interpersonal factors play a significant role in development of inferiority such as Maternal deprivation, Pathogenic family Patterns, Early psychic Trauma, Disordered interpersonal relationships and key stresses of modern life. 


\section{Effect of Home Environment upon Inferiority among School Going Students}

\section{Institutionalization}

In school as compared with an ordinary home, there is likely to be less warmth and physical contact, hence less intellectual, emotional and social stimulation and lack of encouragement is found which again leads to development of inferiority in school going children.

Pathogenic Family Patterns includes parent, child relationships and family interactions. If there is any traumatic experience for the child, it develops inferiority; over protection and under protection is also a common cause of Inferiority.

\section{Hypothesis}

Home environment plays a vital role in the personality development of children. The better the home environment will be, the lesser feeling of inferiority is found in children.

\section{METHOD OF THE STUDY}

\section{Sample:}

Sample consisted of 50 students of local schools. Their age-range was from 5-14 yrs.

\section{Instruments:}

Home Environment Scale:- (Sinha 1985)

Taking home environment under its complexity some important dimensions has been taken which affect the child favorably of unfavorably as the case may be.

The five Dimensions of Home-Environment

(1) Parental Jove and care (PLC)

(2) Family Encouragement and Discouragement (FED)

(3) Identification with family problems (IFP)

(4) Father-mother relationship (FMR)

(5) Family harmony and Discipline (FHD)

The scale has been constructed on Likert pattern consisting of 25 items. The respondents are asked to indicate the applicability of each item on 5 category of answers ranging from "Very much-Tolerable can’t say, very little-Not at all”

Items were selected in such manner that each dimension of Home environment was representated by 5 items. Thus the items selected were as follows:-

$\begin{array}{ll}\text { Dimensions } & \text { Items } \\ \text { PLC } & 1,6,11,16,21 \\ \text { FED } & 2,7,12,18,22 \\ \text { IFP } & 3,8,13,17,23 \\ \text { FMR } & 4,10,14,20,24 \\ \text { FHD } & 5,9,15,19,25\end{array}$

(c) The International Journal of Indian Psychology, ISSN 2348-5396 (e)| ISSN: 2349-3429 (p) | 118 


\section{Effect of Home Environment upon Inferiority among School Going Students}

Out of 25 items, 13 were positive statements and 12 were negative ones.

The Reliability: The measures of reliability were applied for measuring the consistency coefficient of home-environment scale.

The split- half and test - retest reliability index obtained are as follows:

(1) Split half reliability $\mathrm{N}=128 \mathrm{r}=.913$

(2) Test- Retest Reliability $\mathrm{N}=74 \mathrm{r}=.642$

The Validity: The validity of the scale has been used on the rational or adjustment index of the subjects. It was assumed that one who will manifest better adjustment will certainly experience a healthy home-environment, on the contrary that better adjustment is the index of better home environment.

\section{The Inferiority Scale}

The questionnaire consists of 20 questions depending upon the result of pilot study and opinion of several psychologists, 20 items were finally selected out of 30 items originally framed. The question elicits either 'Yes or No' answers.

Reliability:- The test-retest reliability was used for measuring consistency coefficients of inferiority Questionnaire.

Validity:- Self rating by the subjects were obtained on a six point scale as the criterion of determining validity.

\section{ADMINISTRATION AND SCORING}

A questionnaire with full instructions were given and subjects were asked to work their answers in Yes or No. Each answer had been given weight age score for each positive \& Negative answer. The maximum score obtained was hundred.

Scores below 26-Noor low feeling or inferiority between 27- 43 - Mild inferiority feeling between 44-60-Moderate inferiority feeling 61 and Above-Severe inferiority feeling.

Table - 1, Mean, S.D. and Coefficient of Correlation

\begin{tabular}{lllll}
\hline & $\mathbf{N}$ & $\mathbf{M}$ & S.D. & Correlation \\
\hline Home Environment & 50 & 75.5 & 6.06 & .07 \\
Inferiority & 50 & 37.79 & 13.75 & 17.93 \\
& $\mathrm{P}>.05$ & & & \\
& $\mathrm{P}<.05$ & & & \\
\hline
\end{tabular}

(c) The International Journal of Indian Psychology, ISSN 2348-5396 (e)| ISSN: 2349-3429 (p) | 119 
Effect of Home Environment upon Inferiority among School Going Students

Table - 2, Mean, S.D. and t of income scores

\begin{tabular}{llllll}
\hline SES & $\mathbf{N}$ & $\mathbf{M}$ & $\mathbf{S . D .}$ & $\mathbf{t}$ & $\mathbf{P}$ \\
\hline Upper & 18 & 76.39 & 11.37 & & \\
Middle & 18 & 79.89 & 7.89 & 1.07 & N.S. \\
Upper & 18 & 76.39 & 11.37 & & \\
Lower & 14 & 69.79 & 12.48 & 1.54 & N.S. \\
Middle & 18 & 79.89 & 7.89 & & \\
Lower & 14 & 69.79 & 12.49 & 1.54 & N.S. \\
\hline
\end{tabular}

Table -3, Sex and Home Environment

\begin{tabular}{llllll}
\hline SEX & $\mathbf{N}$ & $\mathbf{M}$ & S.D. & $\mathbf{t}$ & $\mathbf{P}$ \\
\hline Male & 28 & 72.67 & 12.09 & & \\
Female & 22 & 79.32 & 13.27 & & N.S. \\
\hline
\end{tabular}

Table -4, Sex and Home Environment

\begin{tabular}{llllll}
\hline Living & $\mathbf{N}$ & $\mathbf{M}$ & S.D. & t & P \\
\hline Urban & 25 & 79.72 & 10.91 & & \\
Rural & 25 & 71.88 & 11.12 & & .05 \\
\hline
\end{tabular}

Table -5, Sex and Inferiority

\begin{tabular}{llllll}
\hline SEX & $\mathbf{N}$ & $\mathbf{M}$ & S.D. & $\mathbf{t}$ & $\mathbf{P}$ \\
\hline Male & 28 & 38.74 & 12.09 & & \\
Female & 22 & 36.25 & 19.00 & 0.53 & N.S. \\
\hline
\end{tabular}

Table -6, Native Place and Inferiority

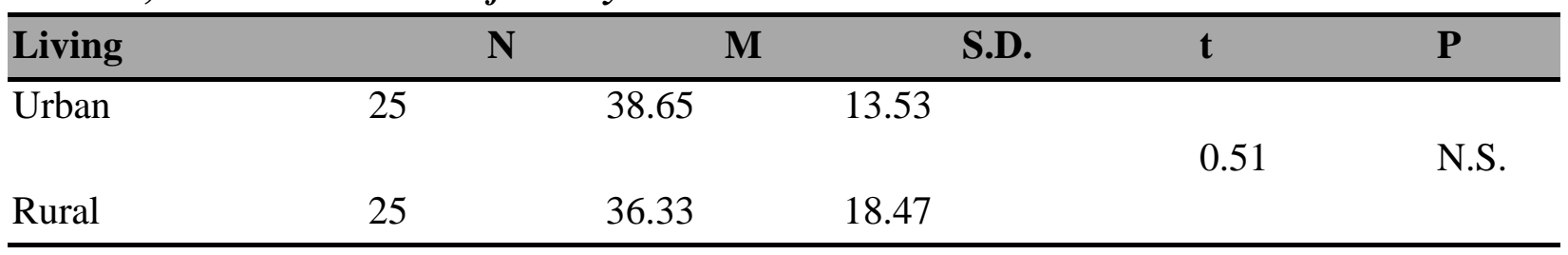

(C) The International Journal of Indian Psychology, ISSN 2348-5396 (e)| ISSN: 2349-3429 (p) | 120 
Effect of Home Environment upon Inferiority among School Going Students

Table - 7, SES and Inferiority

\begin{tabular}{llllll}
\hline SES & $\mathbf{N}$ & $\mathbf{M}$ & $\mathbf{S . D .}$ & $\mathbf{t}$ & $\mathbf{P}$ \\
\hline Upper & 18 & 36.88 & 10.75 & .02 & N.S. \\
Female & 18 & 36.80 & 13.18 & & \\
Upper & 18 & 36.88 & 10.75 & & N.S. \\
Lower & 14 & 40.13 & 18.68 & & \\
Middle & 18 & 36.80 & 13.18 & & N.S. \\
Lower & 14 & 40.13 & 18.68 & & \\
\hline
\end{tabular}

\section{DISCUSSION \& CONCLUSION}

By the statistical treatment done on the basis of date obtained, it is seen that the social stratifications of Home environment sometimes give rise to such a situation which is highly conducive to the emotional expression of inferiority.

Further, home environment is so much elaborate and extensive in the sense that it contains several divisions and dimensions within its domain such as father-mother relationship, parental affection and treatment with their child, their encouragement, discouragement, influences, identification, harmony, discipline etc. All these situations play important role so far as personality development of a child is concerned. No doubt, sometimes, some of these situations pose a threat before the child or adolescent: creating emotional disequilibrium like feeling of inferiority, insecurity etc. It is perhaps due to this that psychologists like Mischel, Allport, Mc. Clelland, Lewin etc. have stressed that behaviour is multiplicative function (i.e. interaction) of personality and environment.

The different hypothesis which was made for this study has been confirmed on the basis of the obtained data and statistical treatment. The proposal passed by UNO in chapter27, that every child in the world has the right to live and it is the parents responsibility to provide a congenial and harmonious home environment for the child, so that he can get various opportunities and motivation to develop skills, confidence and over all perfect personality.

\section{Acknowledgments}

The author appreciates all those who participated in the study and helped to facilitate the research process.

\section{Conflict of Interests}

The author declared no conflict of interests. 


\section{REFERENCES}

D Pandey (2016), Psychological Causes of Residential and Day Scholar School Dropout, International Journal of Indian Psychology, Volume 3, Issue 3, No. 7, DIP: 18.01.133/20160303, ISBN: 978-1-365-12175-3

H Bhut, T Zalavadia (2016) Emotional Maturity and Home Environment among College Student of Rajkot City, The International Journal of Indian Psychology, ISSN 2348-5396 (e), ISSN: 2349-3429 (p)Volume 3, Issue 2, No.5, DIP: 18.01.092/20160302 ISBN: 978-1329-87724-5, http://www.ijip.in, January-March, 2016

Manisha (2016), Scientific Attitude of Scheduled Caste and Non-Scheduled Caste Adolescents in Relation to Home Environment, International Journal of Indian Psychology, Volume 3, Issue 3, No. 9, DIP: 18.01.158/20160303, ISBN: 978-1-365-13820-1

Maslow, A.H. Hirsch Elias - Test of inferiority, Jn. of Gen Psy-1945.

Murray, A.A. - Explorations in Personality, New York oxford university press, 1938.

Rotter, J.B. - Social and clinical Psychology, Englewood cliffs N.J. Princeton- Hall, 1954.

S Mondal, A Sutradhar (2015) Effect of Home Environment on Different Dimensions of Emotional Maturity of Adolescents, The International Journal of Indian Psychology, ISSN 2348-5396 (e), ISSN: 2349-3429(p)Volume 2, Issue 4, DIP: B00319V2I42015, http://www.ijip.in, July -September, 2015

Sinha, R.P. - The home environment scale, 1985.

Yinger, J.M. - Towards a field theory of behaviours, Personality and Social structure, New York, Mc. Graw hill, 1965.

How to cite this article: L Verma (2016), Effect of Home Environment upon Inferiority among School Going Students, International Journal of Indian Psychology, Volume 3, Issue 4, No. 57, ISSN 2348-5396 (e), ISSN: 2349-3429 (p), DIP: 18.01.032/20160304, ISBN: 978-1-365-239939 